\title{
CHALLENGES OF HEALTH CARE PROFESSIONALS' DISCIPLINARY AND CRIMINAL PROSECUTION
}

DOI: 10.36740/WLek202012221

\author{
Marina I. Demura' ${ }^{1}$ Viktoriia A. Kononenko ${ }^{1}$, Nataliia A. Fedosenko ${ }^{2}$ \\ 'YAROSLAV MUDRYI NATIONAL LAW UNIVERSITY, KHARKIV, UKRAINE \\ ${ }^{2}$ NATIONAL AEROSPACE UNIVERSITY "KHAI", KHARKIV, UKRAINE
}

\begin{abstract}
The aim of the research is to study the peculiarities of the legislative consolidation of criminal and disciplinary liability for offenses of health care professionals in Ukraine and other states.

Materials and methods: Criminal legislation of Ukraine, international acts, decisions of the European Court of Human Rights (hereinafter - ECHR), data of the Integrated State Register of Judgments, as well as criminal legislation of Germany, the French Republic, the Kingdom of Denmark, the Republic of Belarus, Kazakhstan and many other countries. A set of general and special scientific methods of scientific knowledge was the methodological basis. The use of the comparative law method has become useful in the analysis of Ukrainian legislation and the legislation of other states.

Conclusions: the article examined the features of the legislative consolidation of criminal and disciplinary liability for offenses of health care professionals in Ukraine and other countries. A comparative legal analysis of the legal enshrinement of the corpus delicti in the form of non-performance or misconduct of professional duties by a health care or pharmaceutical worker was carried out on the example of Ukraine and many other countries; types of penalties for medical crimes, which are established for this type of offense, were identified; sanctions for committing a disciplinary misconduct by a health care professional were determined on the example of the legislation of different countries.
\end{abstract}

KEY WORDS: medical crimes, failure to perform duties, punishment, disciplinary offence, doctor, patient

"If the doctor can't help, do no harm."

Hippocrates

Wiad Lek. 2020;73(12 p. II):2827-2832

\section{INTRODUCTION}

Relations in the field of medical care and responsibility for such actions were in the sphere of customs and morals. For the first time, the issue of prosecuting health care workers for improper performance of their professional duties was raised in the Hammurabi Laws. Thus, $\$ 218$ defined the responsibility of a doctor (for professional activity) - cutting off his fingers for causing death or injury to a human eye. Regulations from Ancient Rome that provided for liability for the improper performance of their professional duties by medical staff have come down to us. Note that such liability was mostly limited to criminal one.

Currently there are different legal traditions in the world regarding the issue of prosecuting health care professionals for improper performance of their duties. Thus, some countries mostly use the practice of civil law settlement of the conflict between a doctor and a patient. These are, in particular, the countries of the Anglo-Saxon legal system - the United Kingdom, the United States, Canada, New Zealand, and many others. It should be noted that in these countries the means of criminal and legal settlement of the conflict are used in exceptional cases, and the means of civil-law nature remain predominant. Other countries use the means of criminal law as a basis for resolving conflicts of this kind and only in exceptional cases they use methods of the other branches of law. Such countries include the post-Soviet countries, as well as Japan, Saudi Arabia and others. The third group of countries combines civil and criminal law when regulating the issue of prosecuting health care professionals for improper performance of their professional duties. This group includes the countries of the Romano-Germanic legal system, in particular, Germany, the Italian Republic, the French Republic and others.

\section{THE AIM}

The aim to study the features of the legislative consolidation of criminal and disciplinary liability for offenses of health care workers on the example of Ukraine and other countries.

\section{MATERIALS AND METHODS}

Criminal legislation of Ukraine, international acts, decisions of the European Court of Human Rights (hereinafter - ECHR), data of the Integrated State Register of Judgments, as well as criminal legislation of Germany, the French Republic, the Kingdom of Denmark, the Republic of Belarus, 
Kazakhstan and many other countries became a material for research. A set of general and special scientific methods was the methodological basis. The use of the comparative law method has become useful in the analysis of Ukrainian legislation and the legislation of other states.

\section{REVIEW AND DISCUSSION}

As defined by the Convention for the Protection of Human Rights and Fundamental Freedoms, "everyone's right to life is protected bylaw" (Article2). The state must guarantee this right to everyone, including when it comes to protecting the right to life of patients. In interpreting this article the ECtHR states in its judgment in Arskaya v. Ukraine (2014) (application no. 45076/05): “... the principles embodied in Art. 2 of the Convention, are applied in the field of public health. The positive responsibilities of the State embodied in this article require States to enact appropriate legislation that would compel public and private health care facilities to take appropriate measures to protect the lives of their patients. These principles also require the establishment of an effective and independent judiciary so that the cause of death of patients due to the actions of health professionals in the public or private sector is established and the perpetrators are held accountable. In the field of medical care, refusal of certain treatment can inevitably lead to a fatal consequence, but treatment carried out without the consent of a mentally competent adult patient will indicate an interference with the physical integrity of the person in a way that affects the rights under Art. 8 of the Convention. However, Art. 2 of the Convention embodies the principle of sanctity (inviolability) of human life, which is evident in the case of a doctor who uses his skills to save lives, and must act in the best interests of the patient... " [1]. Also in its judgment in Csoma v. Romania (2013) (application № 8759/05), the European Court of Human Rights stated: "The Court reiterates that countries that have ratified the Convention "to adopt rules that will oblige both private and public health facilities to take adequate measures to protect the lives of patients" [2]. Such positions of the ECtHR show that the issues of health care workers prosecution are among the issues concerning the observance of fundamental human rights and freedoms and need to be analysed in detail.

Thus, in case of violation of human rights and fundamental freedoms, state coercive measures must be applied to the perpetrators. Such measures of state coercion are legal responsibility. As noted above, different legal measures may be applied in different countries. In Ukraine, criminal, disciplinary, civil and administrative liability can be applied to health care workers.

Let's start the study by analysing the issue of health care workers criminal liability. According to scientists, criminal liability is one of the guarantees of professional performance of their functions by health care workers [3, p. 91]. Quite often crimes in the field of violation of health care legislation are called "medical" crimes.

According to the criminal legislation of Ukraine most medical crimes are concentrated in Section II of the Criminal Code of Ukraine "Crimes against life and health". These include, in particular: improper performance of professional duties, which led to the infection of a person with human immunodeficiency virus or other incurable infectious disease (Article 131 of the Criminal Code of Ukraine); disclosure of information on conducting a medical examination to detect infection with human immunodeficiency virus or other incurable infectious disease (Article 132 of the Criminal Code of Ukraine); illegal abortion (Article 134 of the Criminal Code of Ukraine); illegal medical activity (Article 138 of the Criminal Code of Ukraine); failure to provide care to the patient by a health care worker (Article 139 of the Criminal Code of Ukraine); improper performance of professional duties by a health care or pharmaceutical worker (Article 140 of the Criminal Code of Ukraine); violation of the patient's rights (Article 141 of the Criminal Code of Ukraine); illegal conduct of experiments on humans (Article 142 of the Criminal Code of Ukraine); violation of the procedure for transplantation of human organs or tissues established bylaw (Article 143 of the Criminal Code of Ukraine); forced donation (Article 144 of the Criminal Code of Ukraine); illegal disclosure of medical secrets (Article 145 of the Criminal Code of Ukraine).

Given the limited scope of the article, as well as the need for comparative analysis, we will try to consider only one of the components of crimes in the field of health care. Thus, narrowing the subject of the study, we will analyse improper performance of professional duties by a health care worker in detail. In Ukraine, the responsibility for such acts is established by Art. 140 of the Criminal Code of Ukraine. The choice of this norm of criminal law is due to the fact that, according to experts, "in fact, this is the only article in Ukrainian law, which is used in $90-95 \%$ of cases of any criminal proceedings against health care workers" [4].

Analysis of regulations of other countries and scientific sources of the relevant sphere shows that some of them, such as the Republic of Belgium, the Republic of Bulgaria, the Kingdom of Denmark, the French Republic, do not criminalize improper performance of professional duties by a health care worker in a separate clause, but establish responsibility for careless professional behaviour that harms the life and health of a person. Some countries do not enshrine special rules for prosecuting health care workers in the relevant regulations and establish only liability for crimes against life and health [5] (see Table 1 "Consolidation of criminal liability for medical offenses in different countries").

The conducted scientific research on the issue of criminal prosecution in Ukraine shows the following statistics: in 2018, 654 criminal proceedings were registered under Art. 140 of the Criminal Code of Ukraine, 3 of them were transferred to the court with an indictment, of which only 2 people were convicted. To some extent, this is due to the fact that the results of treatment, unfavourable for a patient, are not always causally related to the actions or inaction of health care professionals, and therefore within the pre-trial investigation in many cases it turns out that there are no grounds for criminal liability $[6, p$. $12]$. We should also add that, in our opinion, such a difference in the number of registered proceedings and actually convicted persons (652) is explained by the fact that practically there are difficulties in applying criminal law, in qualifying the act and gathering evidence, sometimes there is no procedural activity by the victim (or his close relatives or family members). Also one of the reasons is "medical solidarity" by means of which it is possible to hide traces of offenses. 
According to the criminal legislation of Ukraine, improper performance of professional medical duties as a part of a criminal offense belongs to crimes against life and health of a person. The actus reus of the crime is characterized by an act or omission, namely non-performance or improper performance by a heath care or pharmaceutical worker of his or her professional duties due to negligent or dishonest treatment; consequences in the form of severe consequences for the patient; the causal link between these actions and the consequences.

Failure to perform professional duties is a failure to perform actions (complete inaction) by a health care or pharmaceutical professional, while according to the law he was obliged to perform them. Improper performance of professional duties is the performance of one's duties partially, superficially, without complying with the existing requirements for professional activity. These provisions suggest that in fact the regulations do not explain the specific content of this offense. The disposition of the article under consideration is blanket, i.e. when qualifying the committed act it is necessary to establish in each case which professional duties were assigned to the perpetrator and which of them were not performed at all or performed improperly, as well as the requirements of which regulations (orders, instructions, rules, directives, etc.). This is also due to the fact that the profession of a health care worker, including a doctor, is associated with extraordinary situations, each time with new circumstances. In some ways, the current situation complicates law enforcement, and it is impossible to state unequivocally the presence or absence of an offense. Cases from medical practice, at first glance, may seem like medical crimes, and only a full and objective investigation of all the circumstances of the case will help to establish the truth. The above is one of the reasons why the number of proceedings registered and brought to court differs significantly.

According to Ukrainian law, the effect of committing a crime of improper performance of duties by a health care worker is serious consequences for the patient - causing the victim's death, suicide, causing severe or intermediate severe bodily injury, disability or other complication of the disease, causing iatrogenic disease.

Criminal law of Japan, the Kingdom of Belgium, the Netherlands, the French Republic, Romania, the Swiss Confederation considers death or personal injury as a consequences of the crime; in the Republic of Korea - death or physical injury; in the Kingdom of Thailand, the Republic of Albania, Bulgaria, the Kingdom of Denmark, Germany, and the Republic of Poland - death; in the Kingdom of Sweden — bodily injury or disease [5] (see Table 2 "Legislative consolidation of the consequences of committing a crime by a health care worker in different countries").

The conducted analysis gives grounds to claim that in Ukraine there is the widest list of possible consequences of improper performance of professional duties by a health care worker. Note that the existence of such an extended list does not always give the expected results in terms of prosecution. For example, establishing a causal link between a person's suicide and a professional's failure or improper performance of a health care worker's professional duties seems extremely difficult. At present, no cases of proven suicide of a person due to a crime committed by a health care worker have been established in Ukraine.

Returning to the consideration of the elements of criminal offense under Art. 140 of the Criminal Code of Ukraine, it should be emphasized that the object of this criminal encroachment is human life and health, the established procedure for health care and pharmaceutical workers to perform their professional duties.

There is a special subject of the crime- a health care worker, i.e. persons who have the appropriate special education and meet the unified qualification requirements (doctors regardless of profile, paramedics, etc.), as well as persons engaged in private medical practice. To be qualified under Art. 140 it does not matter which category of physicians the perpetrator belongs to - whether he is directly selected by the patient or appointed by the head of a health care institution (subdivision of this institution). That is, in this criminal offense it must be established that the subject of the crime is a health care worker, the crime is committed in the "doctor-patient" system, and, accordingly, the subject is a health care professional, the victim is a patient and the wronged person is a patient or his family.

Similar provisions are contained in the legislation of other countries. The subject of crimes in the majority of criminal codes is a person engaged in relevant professional activities (Republic of Korea, Spanish Republic of Pakistan, Kingdom of Thailand, Republic of Turkey, and Japan).

Here it is necessary to make a small digression and explain that the victim of the crime and the victim in criminal proceedings are not always the same person. This is especially true to a medical crime, one of the components of which is the occurrence of serious consequences: causing the death of the victim, his suicide, causing him severe or intermediate severe bodily injury. Yes, the victim of a crime is a person who has suffered direct damage from a criminal offense, i.e. his life and health have been illegally encroached upon. The victim in criminal proceedings may be an individual who has suffered moral, physical or property damage by a criminal offense, as well as a legal entity who has suffered property damage by a criminal offense (Part 1 of Article 55 of the Criminal Procedure Code of Ukraine). In this case, if a person has died as a result of a criminal offense or the person is in a condition that makes it impossible for him to submit a relevant application, the procedural status of the victim extends to close relatives or family members of such person. The victim is a person among close relatives or family members who filed an application to be involved in the proceedings as a victim, and several persons may be recognized as victims at their request (Part 6 of Article 55 of the Criminal Procedure Code of Ukraine). In conclusion, it should be noted that quite often there are cases when a victim dies as a result of a crime, and a close relative or family member of such person can be referred to as a victim. Thus, in accordance with the legislation of Ukraine, the procedural status of a victim passes to close relatives or family members. A slightly different approach is used in the Criminal Procedure Code of the Republic of Armenia, according to which in case of death of the victim or loss of opportunity to express their will a separate participant in criminal proceedings is introduced - the victim's successor (Article 80) [7]. 
Continuing to consider the corpus delicti provided for by Art. 140 of the Criminal Code of Ukraine, it should be noted that mens rea of a crime is determined by the mental attitude to socially dangerous consequences and is characterized by negligence (criminal arrogance or criminal negligence). In general, the analysis of law enforcement practice confirms that intentional crimes in the activities of health care workers are extremely rare, more often negligent ones occur [8, p. 205].

If a person did not foresee the possibility of socially dangerous consequences, and taking into account the specific situation, could not and should not have foreseen them, the responsibility under Art. 140 is excluded. In this case, there is an accident (incident), an innocent medical error, which cannot be avoided even with the most conscientious attitude to one's professional duties and which can be caused, for example, by the difficulty of diagnosing an unusual disease, anatomical or physiological abnormalities, atypical development of the disease, unexpected allergic reaction, lack of specific (inherent only in cancer) symptoms of early forms of malignant neoplasms [9, p. 329 - 330].

An analysis of the criminal law of other countries shows that the mens rea of this type of crime in other countries is also characterized by negligence.

The sanction of Article 140 of the Criminal Code of Ukraine provides for deprivation of the right to hold certain positions or be engaged in certain activities for up to five years or correctional labour for up to two years, or restriction of liberty for up to two years, or imprisonment for the same term.

Examining the criminal law of other countries we can identify the following sanctions that can be applied to persons guilty of "medical" crime: a fine (legislation of the Republic of Albania, the Kingdom of Denmark, Germany, the Swiss Confederation, the Kingdom of Sweden, the Netherlands, the French Republic, the Kingdom of Spain, Romania, the Republic of Belarus, the Republic of Armenia, the Republic of Kazakhstan, the Republic of Latvia, the Kyrgyz Republic, the Republic of Tajikistan), imprisonment (or incarceration) (legislation of the Republic of Albania, the Kingdom of Spain, the Netherlands, the French Republic, the Republic of Poland, The Kingdom of Sweden, Germany, the Kingdom of Norway, Romania, the Republic of Latvia, the Republic of Tajikistan, the Republic of Lithuania), deprivation of the right to hold certain positions or be engaged in certain activities (legislation of the Republic of Kazakhstan, the Russian Federation, the Republic of Tajikistan); mandatory labour (180 to 240 hours) (legislation of the Republic of Tajikistan); correctional labour to (legislation of the Russian Federation, the Republic of Turkmenistan, the Republic of Belarus, the Republic of Uzbekistan) (see Table 3 "Types of penalties for improper performance of professional duties by a health care worker in different countries").

The above analysis shows that the punishment in the form of deprivation of the right to hold certain positions and correctional labour exist exclusively in the post-Soviet countries. It is also interesting to note that such punishment as a fine is quite common in other countries, but in Ukraine it is not applied to persons guilty of committing a crime under Art. 140 of the Criminal Code of Ukraine.

In addition to criminal liability, medical staff may be subject to disciplinary action for a breach of a duty. If we compare criminal and disciplinary types of liability, then disciplinary liability is a less severe type.

Disciplinary liability of a health care worker is a separate type of legal liability that arises in case of a disciplinary misconduct by a health care worker. Disciplinary liability of health care professionals occurs not only for disciplinary misconduct, but also for violation of moral and ethical norms since workers of this category must comply with the requirements of professional ethics, respect for honour and dignity of citizens (patients). This understanding of disciplinary responsibility is common for a Ukrainian reader. Note the interesting fact that such understanding of disciplinary responsibility is not common to all states. Taking into account the limited scope of the study, it should be noted that we found similar interpretations of disciplinary liability in scientific and regulatory sources of Kazakhstan, Georgia, Armenia, etc.

In general, a disciplinary offence is an unlawful act or omission, which is expressed in non-performance or improper performance of duties and other requirements imposed on the employee under labour law, other special regulations, for violation of which there will be a disciplinary action. Like any offense, a disciplinary offense is characterized by a set of objective and subjective features, called the set of elements of an offense: the subject, the subjective side, the object, the objective side.

Unlawful violations can be defined as a violation of any employment obligations specified in an employment contract, a contract, acts of public authority, instructions of managers adopted within their powers, orders and instructions of the head, if they are legal in nature, and other legal rules. Failure to perform or improper performance of his duties by a health care worker must not only be wrongful, but also consistent with the job function of this employee: the range of rights and responsibilities must be defined in the employment contract, job description, internal labour regulations. Violations of labour discipline established by Ukrainian legislation include:

- Failure to comply with the rules and regulations of technological discipline (violation of instructions for work on medical equipment);

- Systematic violation of labour discipline;

- Absence from work without a good reason;

- Appearing at work in the state of intoxication.

Signs of disciplinary offence are: 1) the fault of an employee (employer);2) illegality of actions (inaction), which are manifested in non-performance or improper performance of labour duties or excess of official authority; 3 ) the causal link between illegal actions (inaction) and harmful consequences. Failure to prove at least one of these elements excludes the availability of a disciplinary offense [10, p. 552].

For violation of labour discipline according to Art. 147 of the Labour Code of Ukraine, an employee can be subject to only one of the following measures of punishment: reprimand and dismissal. As you can see, the types of sanctions for committing a disciplinary offense under the laws of Ukraine, do not differ in their diversity.

In terms of the implementation of comparative law research, we note that in accordance with Art. 223 of the Labour Code of the Republic of Armenia, for violation of labour discipline the following disciplinary sanctions as reprimand, severe rep- 
rimand, termination of employment contract may be applied. In addition, other disciplinary sanctions may be imposed by law on certain categories of employees.

In the Republic of Kazakhstan, such penalties include reprimand, severe admonition, termination of the employment contract at the initiative of the employer. The application of disciplinary sanctions not provided for by the Labour Code and other laws of the Republic of Kazakhstan is not allowed.

In the Labour Code of Georgia there are no references to the definition of disciplinary misconduct and the types of penalties that may be imposed for its commission.

According to Art. 198 of the Labour Code of the Republic of Belarus for committing a disciplinary offense, an employer may apply to the employee the following measures of disciplinary action: reprimand, admonition, and dismissal.

It should be noted that disciplinary action against a health care worker under the law of the above countries may be applied by the body granted the right to hire and dismiss these workers, i.e. the head of the health care facility or a body authorized by him. The right of the head to apply disciplinary sanctions is also enshrined in numerous Regulations on health care institutions and health care staff. For example, in some European countries and the United States there are so-called "professional associations" whose powers are to impose disciplinary sanctions, reprimand, admonition, impose fines, suspend or deprive of the right to practice medicine. We are talking about medical chambers or associations. In almost all European countries health care practitioners, both private and public, are required to be members of the city's health care chamber (association). In the absence of such membership they are not allowed to practice medicine. All members of the chamber (association) make an annual payment. But the main thing is that the members of the chamber must adhere to the Code of Professional Ethics of a doctor, for violation of which disciplinary liability is provided — admonition, warning, fine or expulsion from the chamber (association), which entails the possibility of terminating medical practice. In some countries (Belgium, France, Germany, Switzerland) the provisions of the Code of the doctors' Professional Ethics quite strictly regulate such areas as advertising of medical services, the relationship with the patient, failure to care for the patient, relationships with colleagues. Medical orders (chambers) are non-governmental non-profit organizations that do not provide health care services. Their main function is to represent the interests of doctors and health care organizations, protect the rights of both patients and doctors, and monitor the observance of the Code of Professional Ethics. Chambers (associations) are created on the basis of law, in contrast to public associations, they are associations of public law. In this regard, the European Court of Human Rights in a number of its decisions recognized mandatory membership in the relevant organizations as inconsistent with Art. 11 of the European Convention. The doctor's appeal against the decision of the health care chamber to disciplinary prosecution can be considered by the European Court of Human Rights [11, p. 78-80].

Returning to the Ukrainian legislation we note that, in addition to disciplinary liability, health care workers, in accordance with Art. 130 of the Labour Code of Ukraine are materially liable for damage caused to a health care institution as a result of violation of their duties.
If the necessary grounds and conditions are met then material liability may be imposed regardless of the employee's disciplinary, administrative or criminal liability.

The responsibility for the damage caused to the patient by a health care worker while performing his professional duties rests entirely with the health care institution, regardless of ownership. In turn, a health care institution that is liable as a result of illegal actions of an employed health care professional has the right, in recourse, to file claims against him and prosecute in accordance with labour legislation.

\section{CONCLUSIONS}

Aiming to investigate the peculiarities of the legislative consolidation of criminal and disciplinary liability for offenses of health care professionals in the legislation of Ukraine and other countries we conducted a comparative legal analysis of the crime in the form of non-performance or improper performance of duties by a health care or pharmaceutical worker in Ukraine and other countries; identified types of penalties for medical crimes, which are set by law in different countries; the content and sanctions for committing a disciplinary offense by a health care worker on the example of the legislation of Ukraine and other countries. In particular, it has been established that not every state enshrines the corpus delicti in the form of improper performance of professional duties by a health care or pharmaceutical worker in their law, as did Ukraine, the Republic of Armenia, the Republic of Belarus, the Republic of Kazakhstan, Uzbekistan. Thus, some countries criminalize negligent professional conduct that harms the life and health of a person (Kingdom of Belgium, the Republic of Bulgaria, the Kingdom of Denmark, the French Republic, the Republic of Lithuania). Also, some countries do not provide for liability for improper performance of professional duties by a health care or pharmaceutical worker in a separate article and prosecution is carried out for crimes against life and health (Azerbaijan, Estonia, Georgia, the Republic of Moldova, the Republic of India). Also, on the basis of a comparative legal analysis, the possible consequences of the crime of improper performance of duties by a health care worker were identified. In Ukraine, it is the infliction of death on the victim, his suicide, and infliction of severe or intermediate bodily injuries, disability or other complication of the disease, infliction of iatrogenic disease, in Japan, the Kingdom of Belgium, the Netherlands, the French Republic, Romania or Switzerland - death or bodily injury; in the Republic of Korea - death or physical injury; death in the Kingdom of Thailand, the Republic of Albania, Bulgaria, the Kingdom of Denmark, Germany, and the Republic of Poland; in the Kingdom of Sweden - bodily injury or disease. When considering possible sanctions that could be applied to those guilty of "medical" crime it was found that different countries use their own set of sanctions, in particular, fines (Criminal Codes of the Republic of Albania, the Kingdom of Denmark, Germany, the Swiss Confederation, Sweden, The Netherlands, the French Republic, the Kingdom of Spain, Romania, the Republic of Belarus, the Republic of Armenia, the Republic of Kazakhstan, the Republic of Latvia, the Kyr- 
gyz Republic, the Republic of Tajikistan), imprisonment (or incarceration) (Criminal Codes of the Republic of Albania, Kingdom of Spain, The Netherlands, the French Republic, the Republic of Poland, the Kingdom of Denmark, the Kingdom of Sweden, Germany, the Kingdom of Norway, Romania, the Republic of Latvia, the Republic of Tajikistan, the Republic of Lithuania), deprivation of the right to hold certain positions or be engaged in certain activities; mandatory work; corrective works (Criminal Code of the Russian Federation, the Republic of Turkmenistan, the Republic of Belarus, the Republic of Uzbekistan), etc. The above analysis shows that the punishment in the form of deprivation of the right to hold certain positions and correctional work exist exclusively in the post-Soviet countries. It is also interesting to note that fine is quite common in other countries, but in Ukraine it is not applied to persons guilty of committing a crime under Art. 140 of the Criminal Code of Ukraine.

The study and analysis of international law, as well as the case law of the European Court of Human Rights on health care workers to disciplinary prosecution leads to the conclusion that a major shortcoming of current Ukrainian law is that health care workers, whose proper activities influences on lives and health of people, are subject only to the general rules of labour law. We consider it appropriate to improve the regulations concerning disciplinary liability for improper performance of professional duties of health care workers. Such acts, in our opinion, may be the Statutes or Regulations on the discipline of health care personnel of public, municipal and private health care institutions, which could supplement the existing regulations, as well as the types of penalties provided for in Art. 147 of the Labour Code of Ukraine, such as - reprimand, suspension, etc.

\section{REFERENCES}

1. Case of Arskaya v. Ukraine (Arskaya v. Ukraine) (Application no. 45076/05). Available from: https://ips.ligazakon.net/document/ S0000617 [reviewed 2020.08.14].

2. Case of Csoma v. Romania (Csoma V. Romania) (Application no.№ 8759/05). Available from: https://hudoc.echr.coe.int/ eng?i=001-115862 [reviewed 2020.08.14].

3. Sofiia Lykhova, Iryna Ustynova, Olga Husar and Iryna Tolkachova Topical issues of Criminal Liability of Medical or Pharmaceutical Workers under the Criminal Code of Ukraine (Article 140 of the Criminal Code of Ukraine). International Journal of Advanced Biotechnology and Research (IJABR). Special Issue-1, 2019:87-92.

4. Zozulia N. Osoblyvosti prytiahnennia likariv do kryminalnoi vidpovidalnosti. [Peculiarities of bringing doctors to criminal responsibility] Available from: https://ukrainepravo.com/scientificthought/legal_analyst/osoblyvosti-prytyagnennya-likariv-dokryminalnoyi_vidpovidalnosti-/ [reviewed 2020.02.14] (Ua).

5. Fil I.M. Kryminalno-pravova ta kryminolohichna protydiia nenalezhnomu vykonanniu profesiinykh oboviazkiv medychnym abo farmatsevtychnym pratsivnykom. [Criminal law and criminological counteraction to improper performance of professional duties by a health care or pharmaceutical worker] Dys. ... kand. yuryd. nauk. Kyiv, 2018. 291 s. (Ua).
6. Hutorova N.A., Pashkov V.M. Vidpovidalnist za nenalezhne vykonannia profesiinykh oboviazkiv likarem pid chas vedennia polohiv, shcho sprychynylo tiazhki naslidky (analiz sudovoi praktyky) [Liability for improper performance of professional duties by a doctor during childbirth, which led to serious consequences (analysis of case law).] Medychne pravo. 2019; 2(24):9-25. (Ua).

7. Kryminalnyi protsesualnyi kodeks Respubliky Virmenii. [Criminal Procedure Code of the Republic of Armenia] Available from: http://www. parliament.am/legislation.php?sel=show\& $1 \mathrm{D}=1450 \&$ lang $=$ rus $\# 7$ [reviewed 2020.08.14] (Ua).

8. Medytsynskoe pravo Ukraynd: ucheb. posobye [Medical Law of Ukraine: textbook] V. D. Volkov, L. N. Deshko, V. P. Zablotskyiy dr. Donetsk:Yzd-vo Don NU, 2005. 268 s. (Ua).

9. Naukovo-praktychnyi komentar Kryminalnoho kodeksu Ukrainy [Scientific and practical commentary on the Criminal Code of Ukrain]/ D. S. Azarov, V. K. Hryshchuk, A. V. Savchenko [ta in.]; za zah. red. 0. M. Dzhuzhi, A. V. Savchenka, V. V. Chernieia. 2-he vyd., pererob. i dop. Kyiv: Yurinkom Inter, 2018. 1104 s. (Ua).

10. Velyka Ukrainska yurydychna entsyklopediia. Tom II: Trudove pravo [Great Ukrainian Legal Encyclopaedia. Volume II: Labour Law] redkol.: S. M. Prylypko (holova), M. I. Inshyn (zast. holovy), 0. M. Yaroshenko ta in. 2018. $776 \mathrm{~s}$. (Ua).

11. Williams, John R. (John Reynold) Medical ethics manual: Ukrainian translational by Ukrainian Medical Association (UMA). $140 \mathrm{p}$.

\section{ORCID and contributionship:}

Marina I. Demura: 0000-0002-4806-4105 A, B, C, D, E, F

Viktoriia A. Kononenko: 0000-0002-3999-8862 A, B, C, D, E, F

Nataliia A. Fedosenko: 0000-0002-6615-3937 A, B, C, D, E, F

\section{Conflict of interest:}

The Authors declare no conflict of interest.

\section{CORRESPONDING AUTHOR}

\section{Maryna I. Demura}

Yaroslav Mudryi National Law University

Street Pushkinska, 77, 61002 Kharkiv, Ukraine

e-mail: tlepova.demura.marina@gmail.com

Received: 26.08 .2020

Accepted: 27.11 .2020

A - Work concept and design, B - Data collection and analysis, $\mathbf{C}$ - Responsibility for statistical analysis,

D -Writing the article, E-Critical review, $\mathbf{F}$ - Final approval of the article 